\title{
1 Particle sources and downward fluxes in the Eastern Fram Strait under the 2 influence of the West Spitsbergen Current
}

4 Anna Sanchez-Vidal ${ }^{1 *}$, Oriol Veres ${ }^{1}$, Leonardo Langone ${ }^{2}$, Benedicte Ferré ${ }^{3}$, Antoni Calafat ${ }^{1}$, Miquel 5 Canals $^{1}$, Xavier Durrieu de Madron ${ }^{4}$, Serge Heussner ${ }^{4}$, Jurgen Mienert ${ }^{3}$, Joan O. Grimalt ${ }^{5}$, Antonio 6 Pusceddu $^{6}$, Roberto Danovaro 6

7

81 GRC Geociències Marines, Departament d'Estratigrafia, Paleontologia i Geociències Marines, 9 Universitat de Barcelona, Barcelona, Spain.

2 CNR-ISMAR, Istituto Scienze Marine, Bologna, Italy.

$11{ }^{3}$ CAGE-Centre for Arctic Gas Hydrate, Environment and Climate, Department of Geology, University of 12 Troms $\varnothing$, Troms $\varnothing$, Norway.

$13{ }^{4}$ CEFREM, UMR CNRS 5110, CNRS - Univ. Perpignan, Perpignan, France.

145 Institut de Diagnosi Ambiental i Estudis de l'Aigua (IDAEA), CSIC, Barcelona, Spain

$15{ }^{6}$ Department of Life and Environmental Sciences, Polytechnic University of Marche, Ancona, Italy.

17 * Corresponding author. Tel: +34934021361; Fax: +34934021340. E-mail address: anna.sanchez@ub.edu 18 (Anna Sanchez-Vidal)

Keywords: Particle fluxes, Organic Carbon, Ice Rafted Detritus, Western Spitsbergen Current, Fram Strait

Highlights:

- Downward flux of particles in the western Spitsbergen margin during one year is reported

- Particle fluxes and especially carbon fluxes are strongly sensitive to environmental conditions

- The Western Spitsbergen Current resuspended and transported sediments northwards

- Settling of iceberg-transported IRDs impacted sedimentary and carbon dynamics in winter

- Pelagic settling of marine carbon represented $<28 \%$ of the carbon reaching annually the seafloor 
Abstract

30 Dramatic losses of sea ice in the Arctic have been observed since the end of the 70s. In spite of the global 31 importance of this process that likely witness significant modifications due to climate change, its impact on 32 the carbon cycle of the Arctic has been poorly investigated. Information on organic carbon sources and export, redistribution procesess and burial rates in relation to climate change is needed, particularly in the Arctic land-ocean boundaries. With the aim of understanding the natural drivers that control downward fluxes of particles including carbon to the deep-sea floor we deployed four mooring lines with sediment traps and currentmeters at the Arctic gateway in the eastern Fram Strait, which is the area where warm anomalies are transported northwards to the Arctic. Particles fluxes were collected over one year (July 2010-July 2011) and have been analysed to obtain the content of lithogenics, calcium carbonate, organic carbon and its stable isotopes, biogenic silica, and the grain size. Records of near bottom current speed and temperature along with satellite observations of sea ice extent and chlorophyll-a concentration have been used for evaluation of the environmental conditions.

We found increased lithogenic fluxes (up to $9872 \mathrm{mg} \mathrm{m}^{-2} \mathrm{~d}^{-1}$ ) and coarsening grain size in late winter early spring at the same time than intensification of the northwards flowing Western Spitsbergen Current (WSC). The increased near bottom water temperatures indicated the passage of the warm Atlantic Water core near the bottom of the continental slope. Our data show that the WSC was able to resuspend and transport northwards sediments deposited at the outlet of Storfjordrenna and the upper slope west of Spitsbergen. The signal of recurrent winnowing of fine particles was also detected in the top layer of surface sediments. In addition, an increased arrival of iceberg delivered ice rafted detritus (IRD) (> 414 detrital carbonate mineral grains larger than $1 \mathrm{~mm}$ per $\mathrm{m}^{2}$ ) along with terrestrial organic matter was observed beyond $1000 \mathrm{~m}$ of water depth during winter months. The IRD source areas were the fjords in southwestern Spitsbergen. Finally, the downward particle fluxes showed the typical seasonal cycle of high latitudes, with high percentages of the biogenic compounds (biogenic silica, organic carbon and calcium carbonate) linked to the typical phytoplankton bloom in spring - summer. However, on an annual basis local planktonic production was a secondary source for the downward $\mathrm{OC}$ since most of the $\mathrm{OC}$ was advected laterally by the WSC. Overall, these observations demonstrated the sensitivity of the downward flux of particles to environmental conditions such as hydrodynamics, iceberg calving, and pelagic primary production. It is hypothesized that future alteration of the patterns of natural drivers due to climate change will probably lead to major shifts in the downward flux of particles, including carbon, to the deep sea ecosystems. 
During the past decades, extensive decrease in sea-ice extent and thickness has been reported to be significant in the Arctic (Parkinson et al., 1999; Vinje, 2001; Comiso et al., 2008; Gerland et al., 2008). In particular, after 1996 the sea ice extent shrank at a rate up to 10\% per decade and in summer 2007 there was a massive collapse of ice extent involving a new minimum record of only 4.1 million $\mathrm{km}^{2}$ (Wadhams, 2013). This is an unequivocal sign for climate change (Intergovernmental Panel on Climate Change, 2001, 2007,2013 ) and has raised severe concerns for the vast costs of a melting Arctic (Whiteman et al., 2013). Alterations of seawater salinity and temperature and nutrient distribution may have resulted in changes in marine Arctic ecosystems at all levels of the trophic network (Wassmann et al., 2011), including the distribution and cycling of carbon (MacGilchrist et al., 2014). A recent study carried out in summer 2012, when Arctic sea ice declined to a record minimum, revealed a huge export of organic material of algal origin (up to $9 \mathrm{~g} \mathrm{~m}^{-2}$ ) towards the sea bottom (Boetius et al., 2013). As climate models predict the appearance of largely ice-free summers in the Arctic in the forthcoming decades (Wang and Overland, 2009), increasing inputs of this organic material to the deep sea in the Arctic could be expected (Boetius et al., 2013). The benthic communities inhabiting the deep sea floor are entirely dependent on sinking or advection of particulate organic carbon (McClain et al., 2012). Furthermore, these processes occurring in the Arctic impact the biogeochemical cycles on a global scale (Carroll and Carroll, 2003). It is therefore essential to investigate the sensitivity of natural drivers and deep-sea ecosystem functioning to climate variability.

Our study aims at investigating the spatial and temporal patterns of downward particle fluxes at the transition zone between the North Atlantic and the Arctic Ocean in the western margin off Spitsbergen, which is the largest island of the Svalbard archipelago. This area is very important with regard to heat and water exchange because warm and salty Atlantic Water transported at intermediate depths $(\sim 150-900 \mathrm{~m})$ toward the north is believed to contribute in shaping the Arctic Ocean' ice cover (Polyakov et al., 2012a), which in turn is expected to trigger a number of tipping physical, chemical, and biological processes with potentially large impacts in the Arctic marine ecosystems (Duarte et al., 2012). In the present paper we explore the relationship between hydrodynamic conditions, sea ice extension, primary production, and the total mass fluxes and their composition (including lithogenics, calcium carbonate, organic carbon and its stable isotopes, biogenic silica, and grain size). This research has been framed within the HERMIONE (Hotspot Ecosystem Research and Man's Impact on European Seas) project from the FP7 of the European Commission, which main issue to be investigated was the man's impact in critical sites on Europe's deep-ocean margins (either through the indirect effects of climate change or directly through exploitation of deep-sea resources).

\section{Study area}

The study area is located in the western margin off Spitsbergen, Svalbard Islands, in the south-eastern Fram Strait where the Nordic Seas and the Arctic Ocean connect (Fig. 1). Oceanographic conditions are characterized by the inflow of the West Spitsbergen Current (WSC), that flows northward constituting the northernmost extension of the Norwegian Atlantic Current (Aagaard et al., 1987) and that carries warm Atlantic Water (AW) into the Arctic Ocean (Manley, 1995). At about $79^{\circ} \mathrm{N}$ the WSC splits into two branches, one that follows the perimeter of the Svalbard Islands and flows southwards forming the East Spitsbergen Current, and the other that recirculates flows southwards along Greenland joining the East 103 Greenland Current (EGC) in the western Fram Strait (Quadfasel et al., 1987). While the WSC transports 104 large quantities of heat poleward, the EGC circulates through the area where the main ice outflow from the 105 Arctic occurs (Schlichtholz and Houssais, 2002). 
During its northward flow warm and saline AW loses heat due to surface heat exchange with the atmosphere, and freshens and cools as it mixes with ambient, less saline and cold waters (Saloranta and Haugan, 2004). These cold waters are largely contributed from the fjords. Indeed, fjords in west Spitsbergen can be regarded as coastal polynyas, as the prevailing easterly (offshore) winds over the island lead to a significant cooling of the open water in the fjord (Skogseth et al., 2004) and ice growth. This ice growth triggers an increase in the salinity and density of the ambient waters, involving higher convection and eventually reaching the bottom. Dense water formation due to large polynya events in winter in Storfjorden and Isfjorden ultimately controls the exchange between the fjord and the shelf areas (Nilsen et al., 2008). The dense water produced in the fjords eventually overflows the sill and can reach deep into the Fram Strait (Fer et al., 2008).

The extent of ice in the study area shows a pronounced seasonal cycle. The northern sector of the Svalbard archipelago is intersected by the sea ice (known as the Marginal Ice Zone, MIZ) each year around March when sea ice covers most of the Barents Sea, while the sea ice extent is minimum in September. Irresectively of the increasing interannual variability, the Barents Sea is where largest reductions in sea ice extent have been observed over the last decades (Vinje, 2001; Gerland et al., 2008). In addition, the land-fast sea ice develops in the Spitsbergen fjords in winter and spring starts melting in late spring.

The timing and magnitude of phytoplankton blooms in this region is linked to nutrient input by the inflowing AW and nutrient consumption during the summer productive period, and stratification vs. vertical mixing during winter. The phytoplankton spring bloom usually occurs in April-May with the increase in photosynthetically-active radiation, the decrease of the mixed layer depth, and the stratification induced by ice-melt (Loeng, 1991; Wassmann et al., 2006), and is mainly dominated by diatoms and flagellates (Owrid et al., 2000; Richardson et al., 2005; Carmack and Wassman, 2006). In addition, phytoplankton blooms may develop under the ice over the nutrient-rich shelves of Spitsbergen (Arrigo et al., 2012). Grazing by zooplankton, mainly herbivorous copepods of Atlantic or Arctic origin, decreases phytoplankton stocks and feeds large populations of fish, sea birds and marine mammals (Wassman et al., 2006).

\section{Material and Methods}

\subsection{Remote sensing}

Daily sea ice concentrations have been provided by the National Snow and Ice Data Centre (NSIDC) from the Advanced Microwave Scanning Radiometer - Earth Observing System (AMSR-E) sensor on NASA's Aqua satellite. Maximum and minimum sea ice extents have been obtained from the sea ice concentration dataset computed by applying the ARTIST Sea Ice (ASI) algorithm (Spreen et al., 2008).

Monthly chlorophyll-a (hereinafter chl-a) concentration, with a $4 \mathrm{~km}$ resolution, was obtained by the Moderate Resolution Imaging Spectroradiometer (MODIS) on Aqua satellite. Analyses and visualizations used were produced with the Giovanni online data system, developed and maintained by the NASA GES DISC.

\subsection{Data and sample collection}

Four mooring lines were deployed at $1040 \mathrm{~m}$ (station A, hereinafter $\sim 1000 \mathrm{~m}$ ), $1121 \mathrm{~m}$ (station D, 1120 $\mathrm{m}$ ), $1500 \mathrm{~m}$ (station B), and $2011 \mathrm{~m}$ (station C, 2000 m) of water depth along the western margin of Spitsbergen in the eastern Fram Strait (Fig. 1). Stations A, B and C were equipped with one Technicap PPS3 sequential sampling sediment trap (12 collecting cups, $0.125 \mathrm{~m}^{2}$ opening) at $25 \mathrm{~m}$ above the bottom (mab) collecting 1 sample per month. Mooring B had an extra trap at $975 \mathrm{~m}$ (hereinafter $\sim 1000 \mathrm{~m}$ or 500 
mab, B-Top). Mooring D was equipped with a McLane sequential sampling sediment trap (13 collecting cups, $0.5 \mathrm{~m}^{2}$ opening) at $25 \mathrm{mab}$. The receiving cups of the traps were filled up before deployment with a buffered $5 \%(\mathrm{v} / \mathrm{v})$ formaldehyde solution in $0.45 \mu \mathrm{m}$ filtered arctic seawater.

Each mooring line included an Aanderaa currentmeter (RCM7/9) $2 \mathrm{~m}$ below the sediment trap recording current speed and direction, temperature and pressure with a sampling interval of 1 hour. Stations $A, B$ and $D$ also included a SBE 16 or 37-SMP recording temperature, salinity and pressure at 20-minutes interval at the sediment trap depth near the bottom. Unfortunately, RCM9 currentmeters at stations A, C and $D$ failed due to water leakage, the compass of the near-bottom RCM7 currentmeter at station $B$ was blocked, and the conductivity record at station $D$ was bad. Hence concomitant current amplitude and temperature were solely recorded at $\sim 1000$ and $\sim 1500 \mathrm{~m}$ at station B. Near bottom temperature/salinity measurements were solely collected at stations $A$ and $B$. In addition, CTD and turbidity profiles were collected with a SBE 911Plus probe next to the mooring sites during the deployment (July 2010) and the recovery (July 2011) of the mooring lines.

Seabed sediment sampling was performed in each station, including an extra-station at $615 \mathrm{~m}$ water depth (station E). Sediment samples were obtained with a boxcorer, and the top layer of the sediment $(0-1 \mathrm{~cm})$ collected with a spatula and frozen immediately.

\subsection{Sample treatment and analytical procedures}

After recovering the sediment traps, samples were stored in dark at $2-4^{\circ} \mathrm{C}$ until they were processed in the laboratory with a modified version of the method described by Heussner et al. (1990). Large swimming organisms were removed by wet sieving through a $1 \mathrm{~mm}$ nylon mesh, while organisms $<1 \mathrm{~mm}$ were handpicked under a microscope with fine-tweezers. Samples were split into aliquots using a high precision peristaltic pump robot. One of the aliquots was immediately frozen at $-20^{\circ} \mathrm{C}$ for contaminant analyses. The other aliquots were freeze-dried and weighted for total mass flux determination.

Total and organic carbon $(\mathrm{OC})$ and total nitrogen (TN) contents, and the stable isotope composition of OC, were measured on a Finnigan DeltaPlus XP mass spectrometer directly interfaced to a FISONS NA2000 Element Analyzer via a Conflo II at the Istituto di Scienze Marine (ISMAR-CNR). Samples for OC analysis were first decarbonated after acid treatment $(\mathrm{HCl}, 1.5 \mathrm{M})$ (Nieuwenhuize et al., 1994). Organic matter content was estimated as twice the $\mathrm{OC}$ content, and carbonate content was calculated assuming all inorganic carbon is contained within the calcium carbonate $\left(\mathrm{CaCO}_{3}\right)$ fraction using the molecular mass ratio 100/12. The results of isotopic analyses are presented in the conventional $\delta$ notation.

Biogenic silica (BSi) was analysed using a two-step extraction with $0.5 \mathrm{M} \mathrm{Na}_{2} \mathrm{CO}_{3}$ (2.5 h each) separated after filtration of the leachate (Fabrés et al., 2002). Inductive Coupled Plasma Atomic Emission Spectroscopy (ICP-AES) at the Scientific and Technological Centers of the University of Barcelona was used to analyse $\mathrm{Si}$ and $\mathrm{Al}$ contents in the leachates, and a correction of the Si of the first leachate by the Si/Al relation of the second leachate was applied to obtain the opaline Si concentration (Kamatani and Oku, 2000). Corrected Si concentrations were transformed to BSi after multiplying by a factor of 2.4 (Mortlock and Froelich, 1989).

The lithogenic fraction was calculated assuming $\%$ lithogenics $=100-\left(\%\right.$ organic matter, $+\% \mathrm{CaCO}_{3}+$ $\% \mathrm{BSi}$ ).

Grain size distribution was determined with a Coulter LS230 laser analyzer in samples with enough material left after all major component analyses. A few grams of the freeze-dried sample was oxidized with $10 \% \mathrm{H}_{2} \mathrm{O}_{2}$, and then dispersed in approximately $20 \mathrm{~cm}^{3}$ of water and sodium polyphosphate and mechanically shaken for $4 \mathrm{~h}$. Each sample was then introduced into the particle size analyzer after using a 
$2 \mathrm{~mm}$ sieve to retain coarser particles that might obstruct the flow circuit of the instrument. The measured particle size is presented as volume percentage in a logarithmic scale

Seabed sediment samples were freeze-dried, ground with an agate mortar and homogenized for analyses. The same procedures as those for the sediment trap samples were applied.

\section{Results}

\subsection{Sea ice and chl-a concentrations, and time series of hydrographic conditions}

The maximum and minimum sea ice extension recorded in each month of the studied period is illustrated in Fig. 2. Sea ice was absent from the western margin off Spitsbergen from July to November 2010 except for some land-fast ice in Storfjorden. From late December 2010 to early January 2011 sea ice covered most of the SW part Spitsbergen, and stations $E, A$ and D. Later on, sea ice retreated towards the coast and even disappearing around the Spitsbergen Island. In early April 2011 sea ice grew again and reached stations $E$ and $A$ for a few days. By early May 2011, sea ice started to progressively melt, remaining only in the inner parts of Storfjorden until July 2011

Temporal variations (April-September 2010 and 2011) in the spatial distribution of chl-a concentration are illustrated in Fig. 3. MODIS could not collect data during the months of darkness (October-March). Despite phytoplankton primary production is practically suppressed without irradiance (Boyd et al., 1995; Saggiomo et al. 2002), very low chl-a concentrations can be observed in late winter months also in polar waters (Smith et al., 1991). The chl-a concentration increased over the mooring stations during late springsummer months (April to August 2010 and 2011). Maximum concentrations were recorded in May of both years, while decreasing concentration of chl-a was observed in the continental shelf and in the Spitsbergen fjords in June-July.

The current direction at $1000 \mathrm{~m}$ depth (station B) was highly variable (Fig. 4A), but the mean flow was clearly oriented along-slope toward the NW. Current speed measured at 1000 and $1500 \mathrm{~m}$ at station $\mathrm{B}$ showed similar fluctuations (Fig. 4B and C), but were slightly weaker at $1000 \mathrm{~m}$ depth (median of $7.4 \pm 5.2$

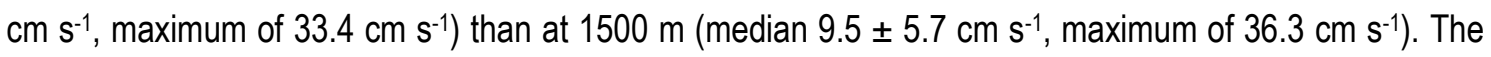
current variations were dominated by low frequency fluctuations of 2-8 days periodicity, and to a lesser extent by semi-diurnal tidal fluctuations. The monthly mean kinetic energy (MKE, an indicator of the low frequency flow variability) and eddy kinetic energy (EKE, an indicator of higher frequency current fluctuations) increased during winter (from mid-February to late March 2011), and spring (from mid-May to end of June 2011) (Fig. 4D).

Low potential temperature $\left(\theta \sim-0.9^{\circ} \mathrm{C}\right)$ and salinity $(\mathrm{S} \sim 34.91)$ measured near the bottom at stations $\mathrm{A}$ and $B$ are characteristic of the Norwegian Sea deep water. Sudden increases in potential temperature $(\theta>$ $0{ }^{\circ} \mathrm{C}$ ) and salinity $(\mathrm{S}>34.92)$ observed in February 2011 at the same depth (around $1000 \mathrm{~m}$ ) at stations $A, B$, and $D$ indicated the inflow of lighter Atlantic Water (Fig. 5). This intrusion is clearly associated with an intensification of the along-slope northward current (Fig. 4B).

\subsection{Total mass and main component fluxes}

Vertical profiles of turbidity collected near the mooring sites in July 2010 and July 2011 showed the presence of a bottom turbid layer about 100-250 m thick at all stations (Fig. 6).

Temporal variations in total mass and main components (lithogenics, $\mathrm{CaCO}_{3}$, organic carbon and $\mathrm{BSi}$ ) fluxes are shown in Fig. 7, and in concentration of main components (as fraction of total mass) are shown in Fig. 8, respectively. 
Temporal series of total mass fluxes at near bottom traps show increased arrival of particles in February-

238 March 2011 specially at the shallower stations A (maximum flux of $11646 \mathrm{mg} \mathrm{m}^{-2} \mathrm{~d}^{-1}$ ) and decreasing 239 northwards along the slope down to station $C$ (maximum flux of $1073 \mathrm{mg} \mathrm{m}^{-2} \mathrm{~d}^{-1}$ ). Particles fluxes then decreased but maintained relatively high levels until the end of the study period in July 2011. A small increase was recorded in June-July 2011 at the deeper stations B and C. In contrast, particle fluxes for the upper trap at mooring $B(500 \mathrm{mab})$ were more or less one order of magnitude lower, and the highest fluxes were recorded in January $2011\left(662 \mathrm{mg} \mathrm{m}^{-2} \mathrm{~d}^{-1}\right)$ and April $2011\left(578 \mathrm{mg} \mathrm{m}^{-2} \mathrm{~d}^{-1}\right)$.

The flux of the main components followed the pattern of total mass fluxes, though with some variations. For the biogenic components, fluxes peaked at $161 \mathrm{mg} \mathrm{m}^{-2} \mathrm{~d}^{-1}$ for OC, and at $56 \mathrm{mg} \mathrm{m}^{-2} \mathrm{~d}^{-1}$ for BSi during the period of elevated sedimentation in March 2011 (Fig. 7). OC and BSi concentrations showed a clear seasonal pattern with low contents ( $<2.5 \%$ for $\mathrm{OC}$ and $1.5 \%$ for $\mathrm{BSi}$ ) from November to May and higher contents during the summer months (June-September). The highest contents were found in the upper trap of station B with values of $10.36 \%$ and $6.74 \%$ of BSi (Fig. 8). For the carbonated and lithogenic fractions, the highest fluxes (up to $1398 \mathrm{mg} \mathrm{m}^{2} \mathrm{~d}^{-1}$ for $\mathrm{CaCO}_{3}$, and up to $9872 \mathrm{mg} \mathrm{m}^{-2} \mathrm{~d}^{-1}$ for lithogenics) were recorded in March 2011 at all stations (Fig. 7). Concentrations of the lithogenic component, which ranged from 57 to $85 \%$, were opposed to those of the biogenic components (OC and $\mathrm{BSi}$ ), with a summer minimum and a winter-spring maximum. Concentrations of $\mathrm{CaCO}_{3}$ varied between 10 and $30 \%$ and roughly mirrored the variations of the lithogenic content

The stable isotope signature of settling $O C\left(\delta^{13} \mathrm{C}\right)$ varied between -23.11 and $-25.54 \%$ (Fig. 8). Small variations were observed during the sampling period, with only sporadic depleted values found in January 2011 at station D, and in June 2011 at stations A, D, and B-Top. The maximum values were recorded during the spring period at all stations. In surface sediments, $\delta^{13} \mathrm{C}$ ranged from $-22.91 \%$ (recorded at the deepest station $C$, which also showed the highest OC content) and $-24.30 \%$ (found at the shallowest station $\mathrm{E}$, which also recorded the lowest OC content) (Table 1).

\subsection{Grain size distribution of settling particles}

Grain sizes of settling particles and surface sediments are shown in Fig. 9 (for sizes $<1 \mathrm{~mm}$ ) and Table 2 (for sizes $>1 \mathrm{~mm}$ ).

Settling particles were predominantly composed of clay $(<4 \mu \mathrm{m})$ and silt-sized $(4-63 \mu \mathrm{m})$ particles, with sporadic contribution of sand-sized $(>63 \mu \mathrm{m})$ particles in January 2011 at station $D$ and March 2011 in station A (Fig. 9). Most of the samples showed the main modes at 4-8 and 20-26 $\mu \mathrm{m}$ (fine silt), while January and March 2011 samples showed modes at 26-40 $\mu \mathrm{m}$ (fine silt) and 56-76 $\mu \mathrm{m}$ (sand).

In addition, very coarse fractions (mostly particles of 2-4 mm but also fine gravel particles up to $8 \mathrm{~mm}$ ) (Table 2) were observed in station $D$ in January 2011. During this month, 207 grains with size larger than $1 \mathrm{~mm}$ were collected. The flux of those large particles, which has been excluded from total mass flux calculations, accounted however 414 grains $\mathrm{m}^{2}$ month-1 $^{-1}$ and $529 \mathrm{mg} \mathrm{m}^{2} \mathrm{~d}^{-1}$ (about one fourth of the fine particle flux). The ice rafted detritus (IRD) consisted of angular grains of detrital carbonate minerals with minor contributions of quartz, gneiss and slate grains (Fig. 10).

Surface sediments at stations $B$ and $C$ were mostly composed of silt sized particles, while sediments at stations $E$ and $D$, which are those closer to the margin, showed high contents of very fine to medium gravel (Table 2). The main modes of fine grained particles involved distributions of 4-12 $\mu \mathrm{m}$ and 22-30 $\mu \mathrm{m}$ 


\subsection{Main oceanographic conditions impacting downward particle fluxes}

282 The western margin off Spitsbergen is strongly influenced by the advection of warm AW with the WSC, 283 which has a strong annual cycle with maximum transport in winter and minimum in summer (Fahrbach et 284 al., 2001). The occurrence of warmer and saltier waters around $1000 \mathrm{~m}$ of water depth in February 2011 is concomitant with the strengthening of the northwards velocities of up to $36 \mathrm{~cm} \mathrm{~s}^{-1}$ (Fig. 4B) suggests that the warm core of the WSC, that usually occupies the upper slope, deepened temporarily during the winter intensification period. This northwards flow may have affected sea ice extent through advection of heat, eddy stirring or double diffusive processes (Vinje, 2001; Saloranta and Haugan, 2004; Divine and Dick, 2006; Polyakov et al., 2012b), and may be responsible for the significant ice melt recorded in March 2011 (Fig. 2). Indeed, the ice edge shifted significantly towards the north and the east, also retreating from the northern fjords (Fig. 2).

Downslope advection of dense, brine-enriched shelf waters overflowing from Storfjorden has not been identified from our data set. Although air temperatures did not reach the abnormally high temperatures recorded in winter 2011-2012 (Nordli et al., 2014), the winter 2010-2011 was also warmer than usual in Svalbard. Indeed the Arctic sea ice extent in February 2011 was one of the lowest ever recorded (Laxon et al., 2013), and even Atlantic pelagic crustacean from temperate waters reproduced in the northern Fram Strait in summer 2011 (Kraft et al., 2013). This prevented massive ice production and salt rejection in Storfjorden in winter 2011 (Jardon et al., 2014), and thus dense water to gain enough density to cascade down the slope and propagate northwards into the Fram Strait (Fer et al., 2008).

During winter 2010-11, only WSC intensification seemed to influence the downward flux of particles. The strengthening of the WSC likely increased the near-bottom fluxes through resuspension of sediment along the upper slope, and transport of fine particles in the bottom layer. The limitation of this transport to the bottom layer is confirmed by the absence of TMF increase in the trap moored at $500 \mathrm{~m}$ above the seabed (B-Top, Fig. 7). Fine grained sediments present at the outlet of the Storfjordrenna (Fig. 1) and the upper slope of the western Spitsbergen margin are likely to be resuspended and transported by the observed near-bottom currents. The recorded current amplitudes were high enough to transport silty particles up to $33 \mu \mathrm{m}$ as suspended load, as calculated by the Sedtrans 05 sediment transport model of Neumeier et al. (2008), which corresponds to one of the main grain size modes for both surface sediments and settling particles (Fig. 9). In addition, the main components ( $\mathrm{OC}, \mathrm{BSi}, \mathrm{CaCO}_{3}$, lithogenic) of the settling particles during this event resembles the composition of the surface sediments (Table 1). Although the WSC intrusion was only detected on the upper slope down to $1000 \mathrm{~m}$, it probably affected the downstream (northward) fluxes of fine particles settling on the deeper part of the slope (1500 m at station B and 2000 $\mathrm{m}$ at station $\mathrm{C}$ ). The presence of a bottom nepheloid layer at the different mooring sites between 600 and $2000 \mathrm{~m}$ depth suggests a relatively permanent availability of fine particles in suspension. Winkelmann and Knies (2005) inferred an active winnowing of fine sediments from outer continental shelf and upper slope sediments west of Spistbergen.

317 This turbid layer and winnowing of fine sediment could be also triggered by other resuspension 318 mechanisms, such as internal waves that produce elevated bed shear stress. Thorpe and White (1988) showed the occurrence of a strong intensification of the near bottom mixing and resuspension of sediments on the deep slope $(2550 \mathrm{~m})$ along the Porcupine Bank. This intensification was attributed to the critical reflection of the dominant M2 tidal wave when it had the same propagation slope as the seabed. Bonnin et al (2006) showed the potential of internal solitary waves in triggering near-bed mixing and resuspension of sediment at the foot of the slope of the Rockall Channel. Although hindered by the 
Levine et al., 1985; D'Asaro and Morison, 1992; Morozov and Paka; 2010; Guthrie et al., 2013), internal wave mixing might possibly lead to sediment resuspension and transport along the slope.

Winter outbursts of lithogenic particle sedimentation reaching values of $83-950 \mathrm{mg} \mathrm{m}^{-2} \mathrm{~d}^{-1}$ were also found by Honjo et al. (1988) and Hebbeln (2000) in the eastern Fram Strait. They were related to lateral advection of dense water from the Barents Sea and IRD inputs, respectively. In both studies the sediment traps were defined at around $500 \mathrm{~m}$ above the seafloor, precluding any interception of resuspended particles from bottom sediments due to intensifications of the WSC. This is to our best knowledge the first study documenting active resuspension and lateral displacement of seafloor sediments by the northward flowing WSC.

\subsection{Downward fluxes of iceberg rafted detritus and terrestrial organic matter}

Increased arrival of detrital carbonate mineral grains larger than $1 \mathrm{~mm}$ (mostly very fine gravel but with contributions of medium gravel) at $1120 \mathrm{~m}$ depth in January 2011 can be regarded as IRD. Ice rafting can occur by icebergs, which transport large and angular particles, and ice, that transport smaller and more rounded particles (Gilbert, 1990). Based on the results of our study (almost exclusively large and angular grains of detrital carbonate minerals, quartz, gneiss and slate) it is most likely that those IRD were icebergtransported. Iceberg calving from point sources at outlet glaciers in the southwestern Spitsbergen Island (Fig. 1) seemed to be the most probably source. Accordingly, the dominant lithology of the coast near Hornsund comprised rocks of very different ages, ranging from Paleozoic to Paleocene-Eocene (Evelvold et al., 2007). The main outcrops showed the presence of Pre-Caledonian basement in the central part of the fjord, formed by metamorphic rocks (phyllites, schists and marbles), flanked by Paleozoic materials (conglomerates, sandstone and shale) and Mesozoic (limestones) to the west (outer fjord), and Cretaceous limestones to the east (inner fjord). This suggests a transport distance of IRD of approximately $64 \mathrm{~km}$.

The $\delta^{13} \mathrm{C}$ signature of $\mathrm{OC}$ enables to investigate the provenance of settling organic matter and thus determine the importance of land derived material settling along with IRDs in January 2011. This approach takes advantage of the distinct signatures of the different types of organic matter typically present in the continental margin (Hedges et al., 1998; Goñi et al., 1988). Hence, terrestrial OC from C3 plants in the Arctic realm shows depleted $\delta^{13} \mathrm{C}$ signatures around -26 to $-28 \%$ (Goñi et al., 2000; Hop et al., 2006; Winkelmann and Knies, 2005) (C4 vegetation in the Arctic is insignificant). In contrast, the $\delta^{13} \mathrm{C}$ signature of marine $\mathrm{OC}$ in Arctic waters is more variable, because slow growing phytoplankton under high concentration of dissolved $\mathrm{CO}_{2}$ at low surface water temperatures show depleted values (-20 to $\left.-26 \%\right)$, while sea-ice algae growing under $\mathrm{CO}_{2}$ limited conditions show highly enriched values (-15 to $-18 \%$ ) (Schubert and Calvert, 2001; Zhang et al., 2012). This variability in the marine signal of $\delta^{13} \mathrm{C}$ leads to some uncertainty in the use of $\delta^{13} \mathrm{C}$ for identification of the organic matter sources. Phytoplankton associated to warm, ice-free and relatively nutrient enriched surface waters from the WSC show a $\delta^{13} \mathrm{C}$ value of $-21 \%$, and that terrestrial derived organic matter show a $\delta^{13} \mathrm{C}$ value of $-27 \%$ (Schubert and Calvert, 2001; Winkelmann and Knies, 2005). Using a two end member isotopic mixing model to determine relative proportions of each of the sources (Hedges et al., 1988; Goñi et al., 2000) we calculate that $75 \%$ of the IRD-derived organic matter is of terrestrial origin. Therefore, iceberg rafting contributed not only with large amounts of very fine to medium gravel but also with terrigenous organic matter. Such inputs from drifting icebergs may substantially affect pelagic and benthic deep sea ecosystems (Smith et al., 2007).

$\mathrm{IRD}$ and terrestrial organic matter were also present in surface sediments at stations $E$ and $D$ (Table 2). Progressively warming winter conditions in the last decades in the area (Walczowski and Piechura, 2007; 
Westbrook et al., 2009; Spielhagen et al., 2011, Ferré et al., 2012) may have resulted in intense iceberg rafting and deposition of land derived material offshore the western Spitsbergen continental margin at depths $500-1120 \mathrm{~m}$. The winnowing of fine grains sediments by recurrent intensifications of the WSC may have left ice rafted boulders outstanding in the seafloor (Winkelmann and Knies, 2005).

The observed data has important implications for paleoceanographic studies. Number of IRD per $\mathrm{cm}^{2}$ of sediment, or number of IRD per gram of dry bulk sediment, have been frequently used as a reliable tracer of iceberg rafting. Indeed, anomalous occurrences of IRD layers have been documented during Heinrich events representing periodic collapses of the large ice sheets (Bond et al., 1992). The grain-size interval chosen to represent IRD has been variable, with higher grain sizes $(>1 \mathrm{~mm})$ near the continental margins and lower ranges $(>150 \mu \mathrm{m})$ in open ocean settings (Hemming 2004, and references therein). Here we show that iceberg calving from glaciers in Spitsbergen during present-day winter conditions is able to bring more than $414 \mathrm{IRD}$ (higher than $1 \mathrm{~mm}$ ) per $\mathrm{m}^{2}$ to depths beyond $1000 \mathrm{~m}$ during 1 month. Rough calculation assuming 1 event of this magnitude per year suggests an IRD flux of $41 \mathrm{~cm}^{-2} \mathrm{ky}^{-1}$, in the higher ranges of those measured during the final deglaciation in Isfjorden (Forwick and Vorren, 2009).

\subsection{Seasonality in primary production and carbon export to the deep seafloor}

The first measurements of $\mathrm{OC}$ flux to the deep sea floor in the eastern Fram Strait took place in the mid80 s by Honjo et al. (1988), and have been measured repeatedly after that (Hebbeln, 2000; Thomsen et al., 2001). In addition, since 2000 the HAUSGARTEN observatory obtained a unique long-term dataset of OC fluxes to the deep Fram Strait (Bauerfeind et al., 2009; Lalande et al., 2013). All authors have reported the typical seasonal cycle of high latitudes characterised by high percentages of the biogenic compounds $\left(\mathrm{BSi}, \mathrm{OC}\right.$ and $\mathrm{CaCO}_{3}$ ) in the downward fluxes linked to the phytoplankton bloom that usually takes place in May and is dominated by diatoms, increased sinking of fecal pellets during summer, and decreasing biogenic contribution towards dark winter months. Furthermore, Lalande et al. (2013) found that anomalous warm years were dominated by small-sized phytoplankton such as coccolithophores over diatoms. Zooplankton fecal pellet production was lower in these years. Our data agrees well with the seasonal cycle described above, and the high $\mathrm{OC}$ and BSi concentrations recorded at the onset (AugustSeptember 2010) and the end (June-July 2011) of the sampling period reflect pelagic primary production in surface waters. Unfortunately, and because mooring deployment and recovery were performed during summer months, the analyses of the complete biological cycle has been interrupted and needs to be examined in the two different years.

Increased chl-a concentration is evident in the western Spitsbergen continental shelf in April 2011 (Fig. 3). Thus, the spring bloom may have developed due to increased solar radiation and ice-melt induced stratification, which favoured the $\mathrm{CO}_{2}$ uptake by primary production of phytoplankton. The patch with high loadings of chl-a increased in May 2011, covered most of the eastern Fram Strait in June 2011, and started to vanish in July 2011.This corresponds well with the BSi and OC concentrations of settling particles that started to increase in May and peaked in June-July 2011 (Fig. 6). OC and BSi concentrations were well correlated (Pearson's correlation coefficient $=0.87, n=59, p<0.01$ ) which is consistent with a link between the processes responsible for $\mathrm{OC}$ and BSi delivery to the seafloor. This suggests that chl-a biomass and primary production were dominated by silica-secreting organisms such as diatoms (Hodal et al., 2012), and thus that diatoms were governing OC export in spring-summer in the eastern Fram Strait as found by Bauerfeind et al. (2009). Recent studies have reported a shift from dominance of diatoms to a dominance of small sized phytoplankton such as coccolithophores during "warm" years (Bauerfiend et al., 2009; Lalande et al., 2013), but our 1 year-round sediment trap experiment does not allow us to relate magnitude of biogenic fluxes to interannual anomalies or trends. 
In addition, a tongue of water with very low chl-a concentration was found in the coastal areas in June

4162010 and 2011 (Fig. 3). This tongue was probably caused by increased freshwater inputs from the island

417 due to melting of snow and ice when air temperatures began to rise consistently above zero, which

418 suppressed phytoplankton growth (Cherkasheva et al., 2014). Together with the melting waters,

419 sediments and inorganic particles may have been released (Beszczyeska-Møller et al. 1997). The

420 depleted $\delta^{13} \mathrm{C}$ values (around $-24 \%$ ) of OC settling in June 2011 at all stations (Fig. 8) suggest that melt

421 water discharge may have also transported terrestrial organic matter beyond the fjords and the

422 Spitsbergen continental shelf, reaching the deep margin.

423 On an annual basis, time weighted fluxes of $\mathrm{OC}$ decreased progressively northwards from $22.1 \mathrm{~g} \mathrm{OC} \mathrm{m}^{-2}$

$424 \mathrm{y}^{-1}$ (station A), $11.8 \mathrm{~g} \mathrm{OC} \mathrm{m}^{-2} \mathrm{y}^{-1}$ (station B), to $6.1 \mathrm{~g} \mathrm{OC} \mathrm{m}^{-2} \mathrm{y}^{-1}$ (station C). Taking into account that 425 primary production in surface waters should not be significantly different among stations (Fig. 4), the 426 observed differences are consistent with decreased inputs of $\mathrm{OC}$ from the slope with increasing water 427 depth. Annual OC fluxes in the trap at 525 mab at station B show values of $4.7 \mathrm{~g} \mathrm{OC} \mathrm{m}^{-2} \mathrm{y}^{-1}$, similar to 428 those obtained by Hebbeln (2000) and Honjo et al. (1988) in the same area. These values may reflect only 429 vertical settling of particles with no influence from resuspension, Using this deposition level as a start point 430 to parameterize the $\mathrm{OC}$ flux attenuation with depth, we obtained that the lateral input of $\mathrm{OC}$ in the lower 431 water column at the $1500 \mathrm{~m}$ depth accounts for approximately $72 \%$ of the total downward flux. Most of this 432 lateral flux is derived from the upper slope areas and has been advected during late winter - early spring 433 due to the reinforcement of the WSC (Fig. 4). Overall this indicates that the strength of the WSC is 434 important not only for the organic carbon budget in the Arctic Ocean but also for the redistribution of 435 carbon (i.e. food supply) to the deep sea fauna inhabiting the western Spitsbergen margin.

\section{Conclusions and implications}

Sedimentary dynamics in the continental margin west of Spitsbergen Island in 2010-2011 was influenced by three main natural drivers that were the northward flowing WSC, the iceberg calving from the nearby

- An intensification of the WSC with AW intrusions was recorded in late winter - early spring 2011, that potentially resuspended and advected bottom sediments, mostly composed of lithogenic material with increased amounts of sand-sized particles. Grain size of both settling particles and surface sediments decreased with increasing water depth northwards, demonstrating the lowering capacity of the WSC to resuspend and transport sediment on the deep slope.

- Settling of iceberg-transported IRDs played also a substantial role in sedimentary and carbon dynamics in the eastern Fram Strait. Increased arrival of IRD larger than $1 \mathrm{~mm}$ was recorded in January 2011 and related to iceberg calving from the Hornsund fjord. In addition, up to $75 \%$ of the settling OC during this event was derived from terrestrial sources. This highlights the importance of Spitsbergen fjords not only as deliverers of IRD but also of terrestrial organic matter to the eastern Fram Strait.

- Finally, primary production dominated by silica-secreting organisms was the main natural driver acting in late spring - summer. However, on an annual basis pelagic settling of OC represented less than $28 \%$ of the OC reaching the deep sea floor.

Our results show that particle fluxes and especially $\mathrm{OC}$ are strongly sensible to environmental conditions, highlighting that the ongoing hydrographic changes in the Arctic Ocean will probably influence the distribution and cycling of $\mathrm{OC}$, including shifting the relative magnitude of the main $\mathrm{OC}$ sources. It has been recently hypothesized that the current sea-ice thinning and increasing melt-pond cover, caused by global warming, may possibly enhance under-ice productivity and ice-algae export (Boetius et al., 2013). 
460 Further, our results pinpoint that warming is expected to result in increased delivery of land derived 461 material including IRD and terrestrial OC in the Arctic Margin by freshwater discharge and iceberg calving. 462 Altogether, these warming-driven changes in rates and composition of inputs to the sea bed will likely 463 promote detectable and significant effects on the whole deep-sea ecosystem.

464 Climate driven changes in the intensity of the northward WSC, which remain open to further confirmation, 465 will determine where terrestrial organic matter reaches higher depths and penetrate these anomalies into 466 the deep Fram Strait ecosystems. While some studies predict an increase of the AW flow into the Arctic 467 (Zhang et al., 1998; Karcher et al. 2003), other recent studies predict a decrease in the number of polar 468 lows over the northeast Atlantic that would imply a potential weakening of the Atlantic meridional 469 overturning circulation (Zhan and von Storch, 2010) and thus the intensity of the WSC (Skagseth et al., 470 2008). While increased WSC intensity would imply widely spreading of terrestrial OC to the deep Fram 471 Strait, decreased intensity would imply less advection and deposition of the terrestrial OC in depocenters 472 near the western Spitsbergen fjords. To acquire a better understanding of all these processes, and assess 473 the impact of climate change on them, further monitoring efforts in polar continental margins are needed, 474 as is being performed for example in the nearby long-term open-ocean observatory HAUSGARTEN 475 (Soltwedel et al., 2005).

\section{Acknowledgements}

478 This research has been supported by the projects HERMIONE (FP7-ENV-2008-1-226354) and GRACCIE479 CONSOLIDER (CSD2007-00067), and a Catalan Government Grups de Recerca Consolidats grant (2009 480 SGR 1305). LL was partly supported by the CNR-DTA project SNOW (Sensor Network for Oceanography 481 in shallow Water - Kongsford experiment), and AS by a "Ramon y Cajal" contract from MICINN. BF is 482 affiliated with the Centre of Excellence: Arctic Gas hydrate, Environment and Climate (CAGE) funded by 483 the Norwegian Research Council (grant no. 223259). We are grateful to S. Buenz and the crew of RV 484 Helmer Hansen (University of Troms $\varnothing$ ) for their valuable support during the cruises, and R. Duran, S. 485 Kunesch, J. Carbonne, A. Rumin, S. Aliani, and X. Rayo who assisted with the field and laboratory work. 486 This is contribution N. XXXX of the CNR-ISMAR of Bologna. 


\section{References}

Aagaard, K., Foldvik, A., Hillman, S.R., 1987. The West Spitsbergen Current: Disposition and water mass transformation. Journal of Geophysical Research 92, 3778-3784.

Arrigo, K.R., et al., 2012. Massive phytoplankton blooms under Arctic sea ice. Science 336, 6087.

Bauerfeind, E., E., Nöthig, A. Beszczynska, K. Fahl, L. Kaleschke, K. Kreker, M. Klages, T. Soltwedel, C. Lorenzen, J. Wegner, 2009. Particle sedimentation patterns in the eastern Fram Strait during 2000-2005: Results from the Arctic long-term observatory HAUSGARTEN. Deep Sea Research Part I 56, 1471-1487.

Beszczyeska-Møller, A., Weslawski, J. M., Walczowski, W. \& Zajaczkowski, M., 1997: Estimation of glacial meltwater discharge into Svalbard coastal waters. Oceanologia 39, 289-298.

Boetius A, Albrecht S, Bakker K, Bienhold C, Felden J, Fernández-Méndez M, Hendricks S, Katlein C, Lalande C, Krumpen T, Nicolaus M, Peeken I, Rabe B, Rogacheva A, Rybakova E, Somavilla R, Wenzhöfer $F$, et al., 2013. Export of Algal Biomass from the Melting Arctic Sea Ice. Science 339 (6126): 1430-1432.

Bond G., Heinrich H., Broecker W. S., Labeyrie L., McManus J., Andrews J.T., Huon S., Jantschik R., Clasen S., Simet C., Tedesco K., Klas M., Bonani G., Ivy S., 1992. Evidence for massive discharges of icebergs into the glacial Northern Atlantic. Nature 360, 245-249.

Bonnin J., Van Haren, H., Hosegood, P., Brummer, G.-J.A., 2006. Burst resuspension of seabed material at the foot of the continental slope in the Rockall Channel. Marine Geology 226, 167-184

Boyd, P.W., S. Strom, F.A. Whitney, S. Doherty, M.E. Wen, P.J. Harrison, C.S. Wong, 1995. The NE subarctic Pacific in winter: I. Biological standing stocks. Marine Ecology Progress Series 128: 1124.

Carmack, E., and P. Wassmann. 2006. Food webs and physical-biological coupling on pan-Arctic shelves: Comprehensive perspectives, unifying concepts and future research. Progress in Oceanography 71, 446-477.

Carroll, M.L., and Carroll, J., 2003. The Arctic Seas. In K. Black and G. Shimmield eds. Biogeochemistry of Marine Systems. Oxford Blackwell Pub Ltd. 127-156.

Carsten J. Schubert, Stephen E. Calvert, 2001. Nitrogen and carbon isotopic composition of marine and terrestrial organic matter in Arctic Ocean sediments: implications for nutrient utilization and organic matter composition. Deep Sea Research Part I 48, 789-810.

Cherkasheva, A., A. Bracher, C. Melsheimer, C. Köberle, R. Gerdes, E.-M. Nöthig, E. Bauerfeind, A. Boetius, 2014. Influence of the physical environment on polar phytoplankton blooms: A case study in the Fram Strait. Journal of Marine Systems 132, 196-207.

Comiso, J.C., C.L. Parkinson, R. Gersten, L. Stock, 2008. Acceleration decline in the Arctic Sea ice cover. Geophysical Research Letters 35, L01703.

D'Asaro, E.A., Morison, J., 1992. Internal waves and mixing in the Arctic Ocean. Deep-Sea Research 39, 459-484.

Day, J.J., Bamber, J.L., Valdes, P.J., Kohler, J., 2012. The impact of a seasonally ice free Arctic Ocean on the temperature, precipitation and surface mass balance of Svalbard. The Cryosphere 6, 35-50.

Divine, D., and Dick, C., 2006. Historical variability of sea ice edge position in the Nordic Seas. Journal of Geophysical Research 111, 2156-2202.

Duarte, C.M., Agustı, S., Wassmann, P., Arrieta, J.M., Alcaraz, M., Coello, A., Marba, N., Hendriks, I.E., Holding, J., Garcia-Zarandona, I., Kritzberg, E., Vaque, D., 2012. Tipping Elements in the Arctic Marine Ecosystem. Ambio 4, 44-55

Elvevold, S., W. Dallmann, D. Blomeier., 2007. Geology of Svalbard. Norwegian Polar Institute, Tromso. $36 \mathrm{pp}$. 
Fabres, J., Calafat, A., Sanchez-Vidal, A., Canals, M., Heussner, S., 2002. Composition and spatiotemporal variability of particle fluxes in the Western Alboran Gyre, Mediterranean Sea. Journal of Marine Systems 33-34, 431-456.

Fahrbach, E., Harms, S., Rohardt, G., Schröder, M., Woodgate, R.A., 2001. Flow of bottom water in the northwestern Weddell Sea. Journal of Geophysical Research 106, 2761-2778.

Fer, I. and Ådlandsvik, B., 2008. Descent and mixing of the overflow plume from Storford in Svalbard: an idealized numerical model study. Ocean Science 4, 115-132.

Ferré B., Mienert, J., Feseker, T. 2012. Ocean temperature variability for the past 60 years on the Norwegian-Svalbard margin influences gas hydrate stability on human time scales. Journal of Geophysical Research 117, C10017.

Forwick, M., and T.O. Vorren, 2009. Late Weichselian and Holocene sedimentary environments and ice rafting in Isfjorden, Spitsbergen. Palaeogeography, Palaeoclimatology, Palaeoecology 280, 258274.

Gerland, S., Renner, A. H. H., Godtliebsen, F., Divine, D., and Løyning, T. B., 2008. Decrease of sea ice thickness at Hopen, Barents Sea, during 1966-2007. Geophysical Research Letters, 35, L06501.

Gilbert R., 1990. Rafting in glacimarine environments. In Glacimarine Environments: Processes and Sediments, Geological Society, London, Special Publication, eds Dowdeswell J.A., Scourse J.D. 53, pp 105-120.

Goñi, M.A., Ruttenberg, K.C., and Eglinton, T.I., 1998. A reassessment of the sources and importance of land-derived organic matter in surface sediments from the Gulf of Mexico: Geochimica et Cosmochimica Acta 62, 3055-3075.

Goñi, M., M.B. Yunker, R.W. Macdonald, T.I. Eglinton, 2000. Distribution and sources of organic biomarkers in arctic sediments from the Mackenzie River and Beaufort Shelf. Marine Chemistry 71 , 23-51.

Guthrie, J.D., Morison, J.H., Fer, I., 2013. Revisiting internal waves and mixing in the Arctic Ocean. Journal of Geophysical Research 118, 1-12

Hebbeln, D., 2000. Flux of ice-rafted detritus from sea ice in the Fram Strait. Deep-Sea Research Part II 47, 1773-1790

Hedges, J.I., Clark, W.A., Cowie, G.L., 1988. Organic matter sources to the water column and surficial sediments of a marine bay. Limnology and Oceanography 33, 1116-1136.

Hemming, S.R., 2004. Heinrich events: Massive Late Pleistocene detritus layers of the North Atlantic and their global climate imprint. Reviews of Geophysics 42, RG1005.

Heussner, S., Ratti, C., Carbonne, J., 1990. The PPS 3 timeseries sediment trap and the trap sample techniques used during the ECOMARGE experiment. Continental Shelf Research 10, 943-958

Hodal H., Falk-Petersen, S., Hop, H., Kristiansen, S., Reigstad, M., 2012. Spring bloom dynamics in Kongsfjorden, Svalbard: nutrients, phytoplankton, protozoans and primary production. Polar Biology 35, 191-203.

Honjo, S., S. J. Manganini, G. Wefer, 1988. Annual particle flux and a winter outburst of sedimentation in the northern Norwegian Sea. Deep-Sea Research 35, 1223-1234.

Hop, H., Falk-Petersen, S., Svendsen, H., Kwasniewski, S., Pavlov, V., Pavlova, O., and Soreide, J. E., 2006. Physical and biological characteristics of the pelagic system across Fram Strait to Kongsforden. Prog. Oceanogr. 71, 182-231.

IPCC, 2001: Climate change 2001: The Scientific Basis. Contribution of Working Group I to the Third Assessment Report of the Intergovernmental Panel on Climate Change, edited by J. J. McCarthy, O. F. Canziani, N. A. Leary, D. J. Dokken and K. S. White (eds). Cambridge University Press, Cambridge, United Kingdom and New York, USA.

IPCC, 2007: Climate Change 2007: The Physical Science Basis. Contribution of Working Group I to the Fourth Assessment Report of the Intergovernmental Panel on Climate Change, edited by Solomon, 
S., D. Qin, M. Manning, Z. Chen, M. Marquis, K.B. Averyt, M.Tignor and H.L. Miller. Cambridge University Press, Cambridge, United Kingdom and New York, NY, USA.

IPCC, 2013: Climate Change 2013: The Physical Science Basis. Contribution of Working Group I to the Fifth Assessment Report of the Intergovernmental Panel on Climate Change, edited by Stocker, T.F., D. Qin, G.-K. Plattner, M. Tignor, S.K. Allen, J. Boschung, A. Nauels, Y. Xia, V. Bex and P.M. Midgley. Cambridge University Press, Cambridge, United Kingdom and New York, NY, USA.

Isachsen, P. E., LaCasce, J. H., Mauritzen, C. and Häkkinen, S., 2003. Wind-driven variability of the largescale recirculating flow in the Nordic Seas and Arctic Ocean. Journal of Physical Oceanography 33, 2534-2550.

Jardon, F. P., F. Vivier, P. Bouruet-Aubertot, A. Lourenço, Y. Cuypers, and S. Willmes, 2014. Ice production in Storfjorden (Svalbard) estimated from a model based on AMSR-E observations: Impact on water mass properties. Journal of Geophysical Research 119, 377-393.

Kamatani, A., Oku, O., 2000. Measuring biogenic silica in marine sediments. Marine Chemistry 68, 219229.

Karcher, M. J., R. Gerdes, F. Kauker, C. Köberle, 2003. Arctic warming: Evolution and spreading of the 1990s warm event in the Nordic seas and the Arctic Ocean. Journal of Geophysical Research 108, 3034.

Kraft A, Nöthig EM, Bauerfeind E, Wildish DJ et al. 2013. First evidence of reproductive success in a southern invader indicates possible community shifts among Arctic zooplankton. Marine Ecology Progress Series 493, 291-296.

Lalande, C., E. Bauerfeind, E. Nöthig, A. Beszczynska-Möller, 2013. Impact of a warm anomaly on export fluxes of biogenic matter in the eastern Fram Strait. Progress in Oceanography 109, 70-77.

Laxon S. W., K. A. Giles, A. L. Ridout, D. J. Wingham, R. Willatt, R. Cullen, R. Kwok, A. Schweiger, J. Zhang, C. Haas, S. Hendricks, R. Krishfield, N. Kurtz, S. Farrell, M. Davidson, 2013. CryoSat-2 estimates of Arctic sea ice thickness and volume. Geophysical Research Letters 40, 732-737.

Levine, M. D., Paulson, C. A., Morison, J. H., 1985. Internal waves in the Arctic Ocean: observations and comparison with lower latitude climatology. Journal of Physical Oceanography 15, 800-809.

Loeng, H., 1991. Features of the physical oceanographic conditions of the Barents Sea. Polar Research, 10, 5-18.

MacGilchrist, G.A., A.C. Naveira Garabato, T. Tsubouchi, S. Bacon, S. Torres-Valdés, K. Azetsu-Scott, 2014. The Arctic Ocean carbon sink. Deep Sea Research Part I 86, 39-55.

Manley, T.O., 1995. Branching of Atlantic Water within the Greenland-Spitsbergen Passage: An estimate of recirculation. Journal of Geophysical Research 100, 20627-20634.

McClain, C.R., A.P. Allen, D.P. Tittensor, M.A. Rex, 2012. Energetics of life on the deep seafloor. Proceedings of the National Academy of Sciences 109, 15366-15371.

Morozov, E.G., Paka, V.T., 2010. Internal waves in a high-latitude region. Oceanology 50,668-674

Mortlock, R.A., Froelich, P.N., 1989. A simple method for the rapid determination of biogenic opal in pelagic marine sediments. Deep-Sea Research 36, 1415- 1426

Neumeier U., Ferrarin C., Amos C.L., Umgiesser G., Li M.Z., 2008. Sedtrans05: An improved sedimenttransport model for continental shelves and coastal waters with a new algorithm for cohesive sediments. Computer \& Geosciences 34, 1223-1242.

Nieuwenhuize, J., Maas, Y.E.M., Middelburg, J.J., 1994. Rapid analysis of organic carbon and nitrogen in particulate materials. Mar. Chem. 45, 217- 224

Nilsen, F., F. Cottier, R. Skogseth, S. Mattsson, Fjord-shelf exchanges controlled by ice and brine production: The interannual variation of Atlantic Water in Isfjorden, Svalbard. Continental Shelf Research 28, 1838-1853.

Nordil et al. 2014. Long-term temperature trends and variability on Spitsbergen: the extended Svalbard Airport temperature series, 1898-2012. Polar Research 33, 21349. 
Owrid, G., Socal, G., Civitarese, G., Luchetta, A., Wiktor, J., Nöthig, E., Andreassen, I., Schauer, U., Strass, V., 2000. Spatial variability of phytoplankton, nutrients and new production estimates in the waters around Svalbard. Polar Research 19, 155-171.

Parkinson, C. L., D. J. Cavalieri, P. Gloersen, H. J. Zwally, J. C. Comiso, 1999. Arctic sea ice extents, areas, and trends, 1978-1996. Journal of Geophysical Research 104, 20837-20856.

Polyakov, I.V. J. E. Walsh, R. Kwok, 2012a. Recent changes of arctic multiyear sea ilce coverage and the likely causes. Bulletin of the American Meteorological Society, 93, 145-151.

Polyakov, I.V., A.V. Pnyushkov, R. Rember, V.V. Ivanov, Y.-D. Lenn, L. Padman, E.C. Carmack, 2012b. Mooring-Based Observations of Double-Diffusive Staircases over the Laptev Sea Slope. Journal of Physical Oceanography 42, 95-109.

Quadfasel, D., J.-C. Gascard, and K.-P. Koltermann, 1987. Large-scale oceanography in Fram Strait during the 1984 Marginal Ice Zone Experiment. Journal of Geophysical Research 92, 6719-6728.

Richardson K, Markager S, Buch E, Lassen MF, Kristensen AS, 2005. Seasonal distribution of primary production, phytoplankton biomass and size distribution in the Greenland Sea. Deep Sea Research I 52, 979-999.

Saggiomo V., Catalano G., Mangoni O., Budillon G., Carrada G.C. (2002) Primary production processes in ice-free waters of the Ross Sea (Antarctica) during the austral summer 1996. Deep-Sea Research Part II: Topical Studies in Oceanography 49(9-10): 1787-1801.

Saloranta, T. M. and Haugan, P. M., 2004. Northward cooling and freshening of the warm core of the West Spitsbergen Current. Polar Research 23, 79-88.

Schauer U., Fahrbach E., Osterhus S., Rohardt G., 2004. Arctic warming through the Fram Strait: oceanic heat transport from 3 years of measurements. Journal of Geophysical Research 109, C06026.

Schlichtholz, P. and Houssais, M.-N., 2002. An overview of the theta - S correlations in Fram Strait based on the MIZEX 84 data. Oceanologia 44, 243-272.

Simmons, H. L., Hallberg, R. W., Arbic, B. K.. 2004. Internal wave generation in a global baroclinic tide model, Deep-Sea Research II 51, 3043-3068.

Skogseth, R., P.M. Haugan, J. Haarpaintner, 2004. Ice and brine production in Storfjorden from four winters of satellite and in situ observations and modelling. Journal of Geophysical Research 109, C10008.

Skagseth, Ø., Furevik, T., Ingvaldsen, R., Loeng, H., Mork, K.A., Orvik, K. A.,Ozhigin, V., 2008. Volume and heat transports to the Arctic Ocean via the Norwegian and Barents Seas, in: Dickson, R., Meincke, J., Rhines, P. (Eds), Arctic Subarctic Ocean Fluxes: Defining the Role of the Northern Seas in Climate. Springer, New York, pp. 45-64.

Smedsrud L.H., Budgell W.P., Jenkins A.D., Ådlandsvik B., 2006. Fine-scale sea-ice modelling of the Storfjorden polynya, Svalbard. Annals of Glaciology 44: 73-79.

Smith Jr. W.O., Brightman R.I., Booth B.C. (1991) Phytoplankton biomass and photosynthetic response during the winter-spring transition in the Fram Strait. Journal of Geophysical Research: Oceans 96 (C3): 4549-4554

Smith K.L., B. H. Robison, J. J. Helly, R. S. Kaufmann, H. A. Ruhl, T. J. Shaw, B. S. Twining, M. Vernet, 2007. Free-Drifting Icebergs: Hot Spots of Chemical and Biological Enrichment in the Weddell Sea. Science 317, 478-482.

Soltwedel T., Bauerfeind E., Bergmann M., Budaeva N., Hoste E., Jaeckisch N., von Juterzenka K., Matthiessen J., Mokievsky V., Nöthig E.-M., Quéric N.-V., Sablotny B., Sauter E., Schewe I., UrbanMalinga B., Wegner J., Wlodarska-Kowalczuk M., Klages M. (2005) HAUSGARTEN: Multidisciplinary Investigations at a Deep-Sea, Long-Term Observatory in the Arctic Ocean. Oceanography 18 (3):4661. 
Spielhagen, R.F., K. Werner, S. Aagaard Sørensen, K. Zamelczyk, E. Kandiano, G. Budeus, K. Husum, T. M. Marchitto, M. Hald, 2011. Enhanced Modern Heat Transfer to the Arctic by Warm Atlantic Water. Science 331, 450-453

Spreen, G., L. Kaleschke, G. Heygster, 2008. Sea ice remote sensing using AMSR-E 89 GHz channels. Journal of Geophysical Research 113, C02S03.

Thomsen, C., Blaume, F., Fohrmann, H., Peeken, Ilka, Zeller, U., 2001. Particle transport processes at slope environments - event driven flux across the Barents Sea continental margin. Marine Geology, $175,237-250$.

Thorpe, S.A., and White, M., 1988. A deep intermediate nepheloid layer. Deep Sea Research 35 (9), 1665-1671.

Vinje, T., 2001. Anomalies and trends of sea ice extent and atmospheric circulation in the Nordic Seas during the period 1864-1998. Journal of Climate 14, 255-267.

Wadhams P. (2013) Diminishing Sea-Ice Extent and Thickness in the Arctic Ocean. NATO Science for

Peace and Security Series C: Environmental Security 135: 15-30.

Walczowski, W., and Piechura J., 2007. Pathways of the Greenland Sea warming. Geophysical Research Letters 34, L10608.

Wang M.Y., Overland J. E., 2009. A sea ice free summer Arctic within 30 years? Geophysical Research Letters 36, L07502.

Wassmann, P., Reigstad, M., Haug, T., Rudels, B., Carroll, M. L., Hop, H., Gabrielsen, G. W., FalkPetersen, S., Denisenko, S. G., Arashkevich, E., Slagstad, D., Pavlova, O., 2006. Food webs and carbon flux in the Barents Sea. Progress in Oceanography 71, 232-287.

Wassmann, P., C.M. Duarte, S. Agusti, M. Sejr. 2011. Footprints of climate change in the Arctic marine ecosystem. Biological Global Change 17, 1235-1429.

Westbrook, G. K., et al., 2009. Escape of methane gas from the seabed along the West Spitsbergen continental margin. Geophysical Research Letters 36, L15608.

Winkelmann, D., and Knies, J., 2005. Recent distribution and accumulation of organic carbon on the continental margin west off Spitsbergen. Geochemistry, Geophysics, Geosystems 6, Q09012.

Zahn, M., and von Storch, H. Decreased frequency of North Atlantic polar lows associated with future climate warming. Nature 467, 309-312.

Zhang, J., A. Rothrock, and M. Steele, 1998. Warming of the Arctic Ocean by a strengthened Atlantic inflow: model results. Geophys. Res. Lett. 25, 1745-1748.

Zhang, R., M. Chen, L. Guo, Z. Gao, Q. Ma, J. Cao, Y. Quu, Y. Li, 2012. Variations in the isotopic composition of particulate organic carbon and their relation with carbon dynamics in the western Arctic Ocean. Deep Sea Research Part II 81-84, 72-78. 


\section{Figure captions}

712

713

714

715

716

717

718

719

720

721

722

723

724

725

726

727

728

729

730

731

732

733

734

735

736

737

738

739

740

741

742

743

744

745

746

747

748

749
Figure 1. Maps of the study area and station location. a) Main currents in the study area: the red arrows show the flow direction of the warm Atlantic Water within the Western Spitsbergen Current (WSC), the blue arrows show the cold East Greenland Current (EGC) and the Eastern Spitsbergen Current (ESC), and black arrow show the overflow plume from Storforden (Brine enriched Shelf Water, BSW). b) Bathymetric map of the study area in the western margin off Spitsbergen with the location of the moored stations A $(1040 \mathrm{~m}), \mathrm{B}(1500 \mathrm{~m}), \mathrm{C}(2011 \mathrm{~m})$, and $\mathrm{D}(1120 \mathrm{~m})$, and the extra-station $\mathrm{E}(615 \mathrm{~m})$. Bathymetric data from IBCAO 3.0 (Jakobsson et al., 2012).

Figure 2. Maximum (red line, marks $95 \%$ ice-concentration isoline) and minimum (blue line, marks $30 \%$ ice-concentration isoline) ice extension and day of the month recorded (number). The location of the moored stations is also shown. The shaded area with no data is caused by the different projection of the obtained sea ice data and the projection used in all figures of this study.

Figure 3. Chlorophyll-a concentration ( $\mathrm{mg} \mathrm{m}^{-3}$ ) during spring-summer months of 2010 and 2011 when sunlight allowed MODIS measurements. The location of the moored stations is also shown.

Figure 4. Times series recorded at station B from July 2010 to July 2011. a) Stick plot of the current at $1000 \mathrm{~m}$ depth at station B; b) and c) times series of current velocity and temperature at $1000 \mathrm{~m}$ and 1500 $m$ at station $B$; d) time series of mean kinetic energy $\left(M K E=\left(\langle u\rangle^{2}+\langle v\rangle^{2}\right) / 2\right)$ and eddy kinetic energy (EKE: $\left.\left(\sigma_{u}{ }^{2}+\sigma_{v}^{2}\right) / 2\right)$ of the current. Energies are estimated using a moving window of 1 month; $\langle u\rangle$ and $\langle v\rangle$ are the average longitudinal and latitudinal components of the current, and $\sigma_{u}$ and $\sigma_{v}$ are the variance of the longitudinal and latitudinal components of the current.

Figure 5. $\theta$-S diagrams from the near-bottom temperature-salinity records from July 2010 to July 2011 at station $A$ at $1000 \mathrm{~m}$ (in red)) and station $B$ at $1500 \mathrm{~m}$ (in blue). Values with $\theta>0^{\circ} \mathrm{C}$ and $\mathrm{S}>34.92$, characteristics of Atlantic Water, mainly appeared during February 2011.

Figure 6. Profiles of turbidity (Formazin Turbidity Unit, FTU) collected next to the mooring sites in July 2010 (solid line) and July 2011 (dotted line).

Figure 7. Time series of total mass flux (TMF, $\mathrm{mg} \mathrm{m}^{-2} \mathrm{~d}^{-1}$ ) and main component fluxes (lithogenics, $\mathrm{CaCO}_{3}$, organic carbon $(\mathrm{OC})$ and biogenic silica (BSi), logarithmic scale, $\left.\mathrm{mg} \mathrm{m}^{-2} \mathrm{~d}^{-1}\right)$ at the four nearbottom traps (25 mab) at stations A ( 1000 m), D ( 1120 m), B (1500 m) and C ( 2000 m), and B-Top ( $1000 \mathrm{~m})$.

Figure 8. Time series of concentration of main components (lithogenics, $\mathrm{CaCO}_{3}$, organic carbon $(\mathrm{OC}$ ) and biogenic silica (BSi), \%) and $\delta^{13} \mathrm{C}(\%)$ values at the four near-bottom traps (25 mab) at stations $\mathrm{A}(\sim 1000$ $\mathrm{m}), \mathrm{D}(\sim 1120 \mathrm{~m}), \mathrm{B}(1500 \mathrm{~m})$ and $\mathrm{C}(\sim 2000 \mathrm{~m})$, and B-Top (1000 m).

Figure 9. Grain size distribution of the fraction $<1 \mathrm{~mm}$ of a) surface $(0-0.5 \mathrm{~cm})$ sediments, and $b)$ settling particles in October 2010 (shaded area) and January 2010 (station D) or March 2011 (stations A, B and C) (black line). Vertical lines show clay $(<4 \mu \mathrm{m})$, silt $(4-63 \mu \mathrm{m})$ and sand $(>63 \mu \mathrm{m})$ sizes.

Figure 10. Photograph of the ice rafted debris (IRD) collected at station $D$ in January 2011 separated by coarse sand $(1-2 \mathrm{~mm})$, very fine gravel $(2-4 \mathrm{~mm})$, and fine gravel $(4-8 \mathrm{~mm})$. 


\section{Tables}

751

752 Table 1. Organic carbon content (OC, wt.\%), biogenic silica $(\mathrm{BSi}, \mathrm{wt} . \%)$, calcium carbonate $\left(\mathrm{CaCO}_{3}\right.$,

753 wt.\%), and lithogenics (litho., wt.\%) and the stable isotope of $O C\left(\delta^{13} C, \%\right)$ of surface $(0-0.5 \mathrm{~cm})$ 754 sediments at all stations. bdl: below detection limit.

755

\begin{tabular}{lcccccc} 
& Depth (m) & $\begin{array}{l}\mathrm{OC} \\
(\%)\end{array}$ & $\begin{array}{r}\mathrm{BSi} \\
(\%)\end{array}$ & $\begin{array}{c}\mathrm{CaCO}_{3} \\
(\%)\end{array}$ & $\begin{array}{c}\text { Litho. } \\
(\%)\end{array}$ & $\begin{array}{c}\delta^{13} \mathrm{C} \\
(\%)\end{array}$ \\
\hline Station E & 615 & $0.84 \%$ & $b d l$ & $9.12 \%$ & $89.21 \%$ & -24.30 \\
Station A & 1000 & $0.90 \%$ & $b d l$ & $13.29 \%$ & $84.90 \%$ & -23.16 \\
Station D & 1120 & $0.89 \%$ & $b d l$ & $6.55 \%$ & $91.66 \%$ & -24.15 \\
Station B & 1500 & $1.12 \%$ & $0.28 \%$ & $14.37 \%$ & $83.11 \%$ & -22.74 \\
Station C & 2000 & $1.13 \%$ & $0.28 \%$ & $14.39 \%$ & $83.07 \%$ & -22.91
\end{tabular}

756

757 
762

Table 2. Grain sizes (vol.\%) of settling particles in January 2011 at station D and surface sediments at stations $E(615 \mathrm{~m})$ to $C(2000 \mathrm{~m})$, including particles $>1 \mathrm{~mm}$. Particle sizes are classified as clay $(<4 \mu \mathrm{m})$, silt $(4-63 \mu \mathrm{m})$, sand $(63-1000 \mu \mathrm{m})$, coarse sand $(1-2 \mathrm{~mm})$, very fine gravel $(2-4 \mathrm{~mm})$, fine gravel $(4-8 \mathrm{~mm})$, and medium gravel $(8-16 \mathrm{~mm})$. Particles $>1 \mathrm{~mm}$ have been considered IRD in the text.

$\begin{array}{cccccccc}\begin{array}{c}\text { Depth } \\ (\mathrm{m})\end{array} & \begin{array}{c}\text { Clay } \\ (\%)\end{array} & \begin{array}{c}\text { Silt } \\ (\%)\end{array} & \begin{array}{c}\text { Sand } \\ (\%)\end{array} & \begin{array}{c}\text { Coarse } \\ \text { sand } \\ (\%)\end{array} & \begin{array}{c}\text { Very fine } \\ \text { gravel } \\ (\%)\end{array} & \begin{array}{c}\text { Fine } \\ \text { gravel } \\ (\%)\end{array} & \begin{array}{c}\text { Medium } \\ \text { gravel } \\ (\%)\end{array}\end{array}$

Settling particles

1120

4.69

11.21

1.26

4.04

43.73

35.05

0

Surface sediments

Station E 615

Station A $\quad 1000$

$\begin{array}{lll}9.36 & 21.63 & 29.31\end{array}$

0

9.02

19.71

71
0

10.96

Station D

1120

19.49

47.05

33.46

0

0

18.16

11.95

Station B

1500

19.81

$14.21 \quad 22.29$

0

67.27

12.30

69.25

7.44

23.31

0

0.62

0
0

0

0

0

(3.31

